\title{
The Semantic Field Theory as Applied to Phraseology
}

\author{
Zulfiia Fazlyeva \\ Institute of Philology and Intercultural Communication of Kazan (Volga region) Federal University, Russia \\ Email: hanifovna@gmail.com, zulkin66@mail.ru
}

\section{Doi:10.5901/mjss.2015.v6n3s2p408}

\begin{abstract}
The article deals with the field method on the whole and as applied to phraseology in particular. Adaptation of semantic field into phraseology sphere is made necessary by the analysis needed within the frames of specified microsystems. Productivity and systematic description of field method may serve alternative to other methods of comparative research. The lexicosemantic system represents combination of semantic fields, with hierarchic structure. On the one hand it provides for the integration into the bigger spheres of lexicon, on the other hand the inclusion into inner structure of the micro-field with not so numerous units. The semantic fields are interconnected and the structure of their boundaries is comparative. Nowadays "a semantic field" term is widely used in the sphere of phraseology as well. Phrase-semantic field can be further subdivided into micro-fields and the last into groups. Such a division is aroused by heterogeneity of the language material examined.
\end{abstract}

Keywords: language field, semantic field, phraseological field, phraseological unit, seme, core, periphery.

\section{Introduction}

The actuality of the article lies in the discovery of the basic principles of the language field, which presents an entire unit of the substantial language layout.

The aim of the work is the different language field theories consideration as applied to lexicology and phraseology.

The possibility of the existence of different types of lexical combinations was surmised by the scholars as early as in the $19^{\text {th }}$ century. For example, Pokrovsky M.M. (Pokrovskiy M.M., 1959.) would single out such kind of combinations in terms of simultaneous application of the three criteria: 1 ) the subject group (it is when the words cover the same range of conceptions; 2) synonymy; 3) morphological relations.

The first theoretical comprehension of the field concept found its application in the articles by German linguists Ipsen G. and Trier J. (Lingvisticheskiy entsiklopedicheskiy slovar', 1990).Trier's ideas excited much interest. By the semantic (or conceptual) field Trier would conceive a specific conceptual sphere structure which corresponds to a wordy (or lexical) language field. Inside of this wordy (or lexical) language field the words are subordinated to the so-called regulation of field articulation, implying every single field contents depends on the words contents entering the field. The fact of the one of the field words modification (the diachronic fact) sets in motion the whole system, resulting in the formation of new contacts net amongst the field members (the synchronicity fact). The availability of a person's awareness of the whole of a word-to-word contact net within the same conceptual field serves the condition of speaking and comprehension.

Trier's research received not only the recognition but critical remarks too. First of all the author was criticized for the absolute parallelism allowed between the wordy (or symbolic) and notional (or conceptual) fields which inter-articulate each other. Secondly, the research material is insufficient to depict the whole map, as Trier used narrow row of lexical units such as nouns, adjectives, but not verbs, for example.

Nevertheless Trier's achievement is in the highlighting of the idea of the field as an entire unit of a substantial language map, also through a thorough historical analysis, his putting it into opposition to formal and onomasiologic principles of language meanings research.

Following Trier's work, Leo Weisgerber (Lingvisticheskiy entsiklopedicheskiy slovar', 1990) gave a more profound theoretical interpretation of the field concept. In language investigation Weisgerber would distinguish philosophical, psychological and sociological aspects. The linguist would differentiate the so-called mono-leveled and multi-leveled fields, with their further division into constituents. Weisgerber's example of a plane field is borrowed from the sphere of kindred relationship. The researcher marks the matter of one of the German language dialects differentiating of a "father's brother" and a "mother's brother" notions, as for the modern German these two relations are conjugated in one notion. Such articulation is called plane by Weisgerber, because the field of the kind can be represented as a level or a plane. 
The mono-levelness of the field lies in the only standpoint (i.e. the principle on which a mono-leveled field is to be chosen), and in this case it is kindred relationship.

The language field development made by Weisgerber differs from that made by Trier due to the research methods of the material entering the field. Weisgerber's approaches the component analysis method that is the meaning's semantic factorization.

The Russian linguists such as Schur G.S., Ufimtseva A.A., Vasiliev L.M., Zvegintsev V.A. and others) have contributed much into the development of the field methodology. The principles of the formation of the language field stated by the Russian linguists have become universally accepted in the linguistic field research. These principles give the following picture of the distinguished features of the semantic fields:

1. Semantic generality of the group constituents.

2. Presence of homogeneous and heterogeneous constituents.

3. Graduation into micro-fields.

4. The field dynamism, which is apparent in the field graduating modification and specific crossing formation. A characteristic feature of the field differing it from other types of the language system is the inner inter-field mutual reaction.

5. The core and periphery presence, where the core is presented by a corresponding language category, of which opposing members perform the cores of the micro-field constituting the field. In the field core the dominant is separated, which is a leading component with closely connected constituents grouped around. The constituents together with the dominant arrange the field's core and form the so-called "perinuclear zone".

6. The groups overlapping and the formation of new zones of gradual group crossing from one into another.

\section{The Field Theory Definition in the Linguistic Studies}

The notion of the semantic field in the linguistic science is represented as a multitude of the language units put together and bound with invariant, meaning "united by the generality of contents and reflecting notional, objectivet or functional similarity of the phenomena highlighted."6(Zvegintsev V., 1989). The unit of the semantic field appears a lexico-semantic variant or a seme. Such lexico-semantic categorical relations as polysemy, synonymy, conversion, antonymy underlying the integrated semantic field units, serve different measuring of semantic field. The units of every semantic field are characterized by a homogeneous conceptual interrelationship.

The whole lexical language system can be broken into some lexical micro-systems, which appear the so-called "maintenance staff" of different conceptual spheres. Accordingly we can single out the semantic fields of kindred relationship, clothing, sadness, gladness and so forth. The lexicon, vocabulary, grouped around a single field, form a single micro-system. The lexico-semantic system represents combination of semantic fields, with hierarchic structure. On the one hand it provides for the integration into the bigger spheres of lexicon, on the other hand the inclusion into inner structure of the micro-field with not so numerous units. The semantic fields are interconnected and the structure of their boundaries is comparative.

Every field has its inner rules under which it is conducted. Moreover the field fulfils its personal world pattern, which is not identical with the analogical phenomenon in other languages and also in the history of the same language, because in the course of time the semantic fields tend to change their structures. The connections between them will change correspondingly, which will lead to modification of the whole language lexical system all in all.

The language fields can be of different degree of difficulty and are characterized by various attribute set. The fields serve a reflection of real connections between language units within the system.

In addition to semantic fields the following types of fields have been separated out by the linguists:

1. Morpho-semantic fields (by Schur, 1974). The essential principle of the field is in a general differential indication, independently of its being whether semantic or morphological, and consequently such types of fields become typical both for the lexicon and grammar.

2. Associative fields (by Bally Sh. Lingvisticheskiy entsiklopedicheskiy slovar', 1990). The fields of the kind are built on the basis of psychological associations of both objects and concepts and their symbols - words.

3. Grammatical fields (by Bondarko A.V., 1984). The core of the field is arranged by paradigmatic systems; the periphery is compounded by non-paradigmatic systems. The central and peripherical zones units are united by a conceptual commonness.

4. Lexico-grammatical field (by Shendels E.I., Gulyga E.V., 1969). The authors have developed the problem of lexical and grammatical meanings interaction, the vocabulary impact on grammatical forms.

5. Function-semantical fields (by Bondarko A.V., 1984). In the languages of widely developed morphology 
system the linguist have separated out a specific area of functional morphology, which combines the morphological forms meaning and functioning.

The language field theory regulations allow giving a profound theoretical analysis of practically all language categories on different languages material.

The field method of linguistic study bears vital character by different reasons. The linguistic field is allocated on the basis of general semantic function of interactive tools of various levels. A generalized semantic attribute singled out here serves a means of interlanguage semantic substratum. The field's structural organization implies components layout into the core and peripheral constituents, which brings to a detailed analyzing of compared language. The field pattern being mobile and dynamic reflects the process of the language grammar evolution. The field method makes possible to mirror the process of compared languages description and also the tendencies of their progress.

A quantitative attribute acts as an essential and important advantage of a field. It helps giving a numerical estimation of language meanings which cannot be imparted grammatically in some languages. The field idea development advances a more serious theoretical analysis of language categories on different languages material. In the lexicology area the semantic fields consider such issues as synonymy, antonymy, polysemy. The field technique promotes interlanguage analogues revelation. A positive field research experience makes a conclusion of the efficiency of such a tendency in modern linguistics. A language field does not fall under a definition of a universal model of contrastive analysis, nevertheless its productiveness and systemacy of description may serve alternative to other methods of comparative research.

The amount of real semantic fields forms an abstract language world model in the upshot. The semantic fields study associates with cognitive psychology models research.

A semantic field's cognitive analogue exists in man's head and corresponds to representation of reality object, usually called "frame" in cognitive linguistics. The overlap between a semantic field and a frame appears in some experience planning representation with the help of various lexical structures, and also in a semantic language area organization.

A theoretical perception of complicated connections between single language substances and conceptual structures, a systematic case study attempt give rise to the necessity of building an ideographic or in other way thesaurus model of a semantic lexical system, meaning classify the hierarchic conceptual system, which provides from meaning to lexical unit retrieval.

\section{The Essentiality of the Field Method Appliance}

Nowadays "a semantic field" term is widely used in the sphere of phraseology as well. First it was Kunin A.V. (Kunin A.V., 1986) who substantiated a necessity for semantic field analysis as applied to phraseology. The linguist has grounded an essentiality of phraseological units' analysis within the limits of specific micro-systems. Currently in linguistics there can be emphasized two approaches towards phrase-semantic fields. The first approach deals with the fact of both phraseological and lexical language units provide members of phrase-semantic field. The theory adherents are convinced a phraseological unit is equivalent to a word. For the type of a field the term "a lexico-phraseological field" is introduced. It presents aggregate of categorically homogeneous lexical elements and phraseological combinations, united by mutual invariant.

The second approach linguists consider phraseological units form specific phraseological fields. The phenomenon is substantiated by peculiar meanings of phraseological units, a special character of the reality reflection they present, different inter-field organization and paradigmatic and syntagmatic connections within the field.

A linguist Ganapolskaya E.V. (Ganapolskaya E.V., 1995) would say: "there is a sense in choosing a single semantic field and lexical, phraseological and paremiological (that is of proverbs and sayings) fragments within its framework." Here we do not agree with the opinion of a phraseological unit's specific character being equivalent to a word, that is why we think lexis should be excluded from a phrase-semantic field. As regards paremiology, we suppose it should enter the phraseological language system as far as the proverbs and sayings bear all the constitutive features the phraseological units have. They come forward as language units and can not only be used as a communicative discourse speech sentence unit, but also as a part of a sentence. We define a phrase-semantic field as a relatively autonomous, systematized group of phraseological units, united by a specific notional invariant.

Phrase-semantic field can be further subdivided into micro-fields and the last ones into groups. Such a division is aroused by heterogeneity of the language material examined.

The leading element in the construction of the semantic fields is a phraseological unit meaning. It is impossible to single out the unit which would present the whole sense, with all the other meanings subjected to it. Consequently, a 
significant role of the leading component of the phrase-semantic field should be given to a general notion.

We define here a phrase-semantic field as a relatively independent and systematized group of phraseological units, consolidated under a certain general meaning.

\section{Procedure}

Our research is dedicated to a family notion, which offers a system of human being relations. Family is one of the fundamental features of society and concerns its every member independent of his or her gender, occupation or confession. The family phenomenon presents rich material for the analysis, not only in the field of sociology, but also linguistics, especially phraseology. "The role of the social factors in phraseology development is particularly great, they influence the proverbs, sayings and other set units formation. In them we will find a summarized characteristic of the social experience, popular wisdom and also semantic phenomena of different kind, arising from the eternal impact." (Desheriev Y.D.,1977).

The study of a phrase-semantic field of a "family" notion is of a separate interest, as in our research the phraseological units of two distant, genetically unrelated, noncontact languages - English and Turkish - are subjected to comparison. Both the languages differ in culture, religion, ethical values, thus varying in a view of family institution.

Proceeding from the fact of family being a social institute, we turned to sociology with a view of the detailed analysis of the occurrence structure. Relying on the main characteristics and family life organization we have constructed a scheme of a phrase-semantic "family" field. The scheme allows to classify the phraseological units of the field under study according to the themes and correspondingly to the micro-fields.

Within the frames of the phrase-semantic "family" field we have analyzed the set phrases of the English and Turkish languages. The study of the phraseological units of the English language entering the field has showed a somehow ironical approach of the English people towards family life, for example - "double harness" and "ball and chain: - both with the meaning of "matrimony, wedlock".

In the Turkish language such phrases are absent.

Both the cultures are not well-disposed towards a husband being henpecked, having no say in his family. The occurrence is most strongly expressed in the English language phraseology: the grey mare is the better horse; be under somebody's thumb; be pinned to one's wife's apron strings; to live under a cat's foot; wear the breeches; a hen-pecked husband. The Turkish language is not much sprinkled with such examples: "kocanın kalbı ikiyse, birini kır" - about a woman who has grown fastidious (Alper Yildirim, 20106, Oy Aydın, 1972).

The reason of the fact being thrown light upon in the English language lies in the following deduction: the English phraseological units show the coherence of the family being subdue to a husband mostly: "a good husband makes a good wife"; "a good Jack makes a good Jill". As for the phraseology of the Turkish language a husband would always be the earner - "erkek sel, kadın göl" ("a husband is a tributary, a wife is a lake"), but it is always a wife (according to set phrases) who is responsible for a happy and sound family: "kadın kocasını isterse vezir, isterse rezil eder"(a wife can make either a vizier, or a disgrace out of her husband); "evi ev eden avrat" (a kind hostess); "ocğın yakışığı odun, evin yakışı̆ı kadın"(a wife for home is as firewood for the furnace).

Through the study of "the children" seme we have found out that a distinguishing feature of the seme is a large number of nominative phraseological units especially in the English language, and they reflect the similarity of children to their parents, for instance: "like father, like son" (eng.) - "babasının oğlu" (turk.)

The relationships of brothers and sisters are not depicted in the English phraseology, but are present in the Turkish language. For example the following three set phrases of the Turkish language show the sense of "the brothers will fight and then will they make peace with each other": "Kardeş kardeşi atmış, yar başında tutmuş";

"Kardeş kardeşi bucaklamış, dönmüş, yine kucaklamış";

"Iki kardeş savaşmış, ebleh buna inanmış";

The phraseological unit of the same subject - "kardeşım olsun da kanlım olsun" - has got the meaning "it is always good to have a brother or sister - he or she will always of help".

\section{Result}

We have classified the phraseological parallels according to the thematic and semantic principle.

Under the primary constituent of the unit the following micro-fields have been picked out:

1. "Marriage" - to here the next units can be referred: "the answer to a maiden's prayer", "bridegroom's men", "Mr. Right" (eng.), "guvey girmek" (turk.); "bride's favours", "Miss Right" (eng.), "alacak kiz ay gorunur" (turk.); 
"ask the banns", "jump over the broom-stick", "a left-handed marriage", "to throw the handkerchief", "marriages are made in heaven" (eng.), "dunya evine germek", "gorucuye cikmak", "dunur gitmek" (turk.);

2. "Family circle», with the following units: "keep the home fires burning", "in the bosom of one's family", "an Englishman's home is his castle", "hearth and home", "Lares and Penates", "under one's vine and fig-tree" (eng.), and with negative connotation in the Turkish language: "ocagina incir dikmek", "ocagi kor kalmak", "ocagina dar ekmek", "ocagini sondurmek", "ev yikmak" with the meaning of "putting one's hearth out".

3. "A child birth" micro-field is introduced by the following phraseological units: "to be big with child", "in the club", "in a family way", "be in a certain condition", in the Turkish language these are - "ana hali olmak" (be big with a child), "iki canli"(with two souls), "anasi kadir gecesi dogurmus"(be born with a silver spoon in one's mouth).

4. "A husband and a wife" group includes such equivalent phraseological units of the languages compared as: "one's old Dutch", "one's better half", "good lady" (eng.), and "can yoldasi", "hayat arkadasi" (turk.). As for the Turkish phraseological units they declare a liberal share of deductive when speaking of a wife: "evine gore pisir asini, erine gore bagla basini"; "evine gore bagla basini, tencerene gore kaynat asini" (put on your shawl as your husband demands and prepare food as the folks ask); "erkegin kalbine giden yol midesinden gecer" (the way to a man's heart is through his stomach).

5. "Children" micro-field is represented by the leading components of "a son" and "a daughter". A distinguishing feature of the group lies in the large amount of nominative units, especially in the English language, which reflect children's resemblance to their parents. For example: (about a daughter) "like mother, like daughter"; "mamma's darling"; "as the tree, so the fruit"; "like mother, like child". (About a son) - "a chip of the old block"; "as the old crock crows, so doth the youth"; "mother's darlings make but milksop heroes"; "like father, like son"; "son of a sea-cock"; "son of a gun" (informal). The Turkish phraseological units show metaphorical approach: (about a daughter) "ananin ciktigi dala kizi salincak kurar" (a daughter hangs up her swing on her mother's branch) "anasinin kizi"; "anasinin korpe kuzusu"; "ana kuzusu" (one mother's darling, one mother's lamb). About a son - "babasinin oglu"; "kan cekmek"; "agaca cikan kecinin dala bakan oglagi olur".

6. Under "Kinfolk" group can be brought the phraseological units with the seme related to blood relatives and collateral, for instance, here a Turkish set phrase with "an uncle" component can be cited - "baba yarısı" (uncle is a father's soul mate) - the phrase emphasizes respect towards the kin.

The analysis of "the daughter-in-law" seme brings to light some interesting results. The image of the daughter-inlaw draws the impression of a sharp and bald young lady. Such Turkish phraseological units have no analogue in the English language. The group of phrases conveys sarcastic attitude towards the daughter-in-law: "gelin atta buyuruk Hak'ta" (when the daughter-in-law rides the horse, her command is law - that is "the daughter-in-law rules"; "gelin hali getirir, serer kendi oturur" (the daughter-in-law came, brought a carpet with her, laid it and sat upon it) (Alper Yildirim, 20106, Oy Aydın, 1972, Kunin A.V., 1984).

On the whole a distinctive characteristic of the English phraseological units is humor, conciseness and exactness of definition. The Turkish phraseological units are characterized by instructive and serious point of view. The specific feature of the last is in the extended sentences, essential quantity of sayings.

\section{Conclusion}

Generally, a family phenomenon definition, specifying of its structure and interpersonal relations make common for both the languages compared. The conformity of the phraseological units is evident of some solidarity of associative thinking of the speakers of the languages engaged. The inequality in the phraseological system of the analyzed languages reveals itself in the structural and grammatical arrangement, brought to light by the distance and difference in their body and relation of both the languages. Predominance of specifically national formations in a phrase-semantic field can be explained by the language body historical experience and cultural uniqueness.

Thus, to make our research proper the phraseological body has been subdivided into a definite number of semantic communities so that the principal micro-fields of a phrase-semantic "family" field could be set up. With the help of these phrase-semantic fields the common tendencies of the out-of-language reality could be detected.

\section{References}

Alper Yildirim (2010. pp.558.) Yeni Atasozleri ve Deyimler Sozlugu. Istanbul: Bilge Kultur Sanat,

Bondarko A.V. (1984 №6.) O grammatike phunktsionalno-semanticheskih poley.Izvestia AS USSSR. Seria Literatura I Yazyk, Desheriev Y.D. (1977, p.167) Sotsialnaya lingvistika. 
Ganapolskaya E.V. (1995. pp.337, p.21) Phraseosemanticheskoe pole "Trud" v russkom yazyke (v sopostavlenii s angliyskim). (Phd Thesis), SPB.

Gulyga E.V., Shendels E.I. (1969, pp.184) Grammatiko-leksicheskie polya v sovremennom nemetskom yazyke. M. "Prosveshenie". Kunin A.V. (1986, pp.336) Kurs sovremennogo angliyskogo yazyka. M.

Kunin A.V. (1984, pp. 942) Anglo-russki phraseologicheski slovar: M.

Lingvisticheskiy entsiklopedicheskiy slovar' (1990, p.172.) M."Sovetskaya entsiklopediya".

Oy Aydın (1972, 300 pp.) Tarih Boyunca Türk Atasözleri. - İstanbul.

Pokrovskiy M.M. (1959) Izbrannye raboty po yazykoznaniyu, M.

Schur G.S. (1974, pp.225) Teoriya polya v lingvistike, M.

Zvegintsev V. (1989, p. 567) Novoe v zarubezhnoy lingvistike, Cb.ct., M."Progress", vyp.10. 